\title{
Dinheiro e reciprocidade nos Cinta-Larga: notas para uma economia política na Amazônia meridional'
}

\author{
João Dal Poz Neto \\ Doutor em Ciências Sociais (Universidade Estadual de Campinas) \\ Professor da Universidade Federal de Juiz de Fora \\ Juiz de Fora, MG, Brasil \\ idalpoz@ig.com.br
}

\begin{abstract}
Resumo Entre os Cinta-Larga, através de um fluxo contínuo de bens e serviços, os interesses do chefe político entrelaçam-se aos dos moradores de sua aldeia. E, no contexto contemporâneo de suas relações exteriores, uma espécie de contabilidade qualitativa de acordos e dívidas (em torno da venda de madeira e da exploração de garimpos) associa-os a uma gama variada de atores e instituições sociais. Assim, as instâncias de negociação e os mecanismos de controle financeiro tornaram-se um espaço ampliado de disputas entre chefes, aldeias e associações. Este artigo descreve as formas locais de apropriação, circulação e uso do dinheiro, que evidenciam a semântica do endinheiramento que ali se desenvolveu nas três últimas décadas.
\end{abstract}

Palavras-chave: Cinta-Larga, Tupi-Mondé, Amazônia meridional, economia política, etnografia do dinheiro.

\section{A propósito}

$\mathrm{T}$ RANSAÇÕES COM MADEIREIROS E GARIMPEIROS, sobretudo nas três últimas décadas, impulsionaram vigorosamente a série de transformações que se observa nos povos de língua tupi-mondé da Amazônia meridional - dentre os quais, os afamados Cinta-Larga. ${ }^{2}$ Fonte primária de receitas monetárias vultosas e crescentes, não obstante, a associação com tais franjas de nossa "economia capitalista" parece antes responder a um modelo cultural orientado pela reciprocidade assimétrica e desigual, nos termos de uma "economia da predação", que converte aqueles seres e qualidades exteriores em valores indispensáveis às suas próprias operações internas. $\mathrm{O}$ esboço de alguns aspectos desse novo ciclo etnográfico, cujos contornos são ainda pouco precisos,

1 Uma versão anterior deste artigo foi discutida no fórum de pesquisa Os Sentidos Sociais do Dinheiro: Perspectivas Etnográficas, coordenado por Omar R. Thomaz (Unicamp) e Federico Neiburg (UFRJ), na $26^{\text {a }}$ Reunião Brasileira de Antropologia, de $1^{\circ}$ a 4 de junho, em Porto Seguro (BA). Agradeço aos coordenadores e demais participantes os comentários e as sugestões à Fapemig, que me possibilitou a viagem para lá.

2 Com um total de 2,7 milhões de hectares, o território cinta-larga, para efeitos administrativos, compõe-se de quatro áreas contíguas (parque do Aripuanã, 1.603.246 hectares; Roosevelt, 230.826 hectares; Serra Morena, 147.836 hectares, e Aripuanã, 750.649 hectares), abrangendo parcelas de vários municípios de Mato Grosso e Rondônia. A população cinta-larga soma hoje cerca de 1.500 pessoas, distribuídas em mais de 30 aldeias e postos da Funai. 
talvez consiga justificar, se não esclarecer, a presente hipótese de trabalho. Desde seus primórdios nos anos 80, a extração ilegal de madeira e as atividades garimpeiras ali jamais cessaram, sequer seus motivos e suas implicações. Nos últimos anos, o foco principal dessa nova economia política deslocou-se para as margens do igarapé Lage, um afluente do rio Roosevelt, no setor oeste do parque do Aripuanã, após a descoberta de uma enorme jazida de diamante a "céu aberto" que atrai a cobiça de milhares de garimpeiros, empresários de mineração, cartéis internacionais e traficantes de pedras preciosas.

Incontornáveis, de todo modo, são os significados que os próprios ameríndios deram a esses fatos, bem como suas repercussões mais gerais - como se sabe, para muitos, mesmo o inesperado contato com os "europeus civilizados" não teria sido orquestrado apenas como uma cesura no plano histórico (Albert \& Ramos, 2002). É o que disse um líder cinta-larga, na reunião com representantes do Ministério Público Federal e da Funai (Cacoal-RO, em março de 2002):

Nós antigamente éramos diferentes, [éramos] guerreiros. Matava quem matava o irmão. Tinha pagamento. Agora não...

Como nós descobrimos o garimpo? Quem quer trabalhar com o garimpo? [...]

Hoje nosso parente morreu [dias antes, um homem cinta-larga fora assassinado numa cidade próxima], e nós estamos alegres, comendo pão, café, estamos alegres. Antigamente não era assim, tinha vingança [pagamento].

Quero que a gente cumpra o que combinou, honestidade. Nós temos que melhorar nossa vida. Não acabar, morre um, morre outro. Nós temos que fazer o que nossos pais faziam. Cadê colar? Só usa roupa, cada um tem seu celular, que nem vocês [as autoridades convidadas]. Vocês [as autoridades] podem pensar que nós somos brancos, vestidos assim.

Nós não queremos acabar. Vocês precisam ajudar.

$\mathrm{Na}$ etnologia sul-americana, os fenômenos da guerra, do canibalismo e do xamanismo, temas caros às sociedades tupis, foram descritos como mecanismos de produção de diferenças sociais por meio de inimigos interpostos, ao que se denominou de "economia simbólica da predação” (Viveiros de Castro, 1993) ou da "alteridade" (1996). Determinada paradoxalmente por seu exterior, tais formas de sociabilidade desdobrar-se-iam pela apropriação de identidades e qualidades metafísicas alheias e definiriam a noção de pessoa nos termos de uma trajetória centrífuga, de um "devir Outro" - afins, parceiros, inimigos ou deuses, dentre outras figuras da alteridade.

Todavia, na vida diária o trabalho de mediação da violência, forçosamente, encontra-se deslocado pela reiteração ideológica e ritual de trocas recíprocas, sendo esta a "condição ideal" da sociabilidade humana (Dal Poz, 1993). Trata-se, aliás, de um esquema cosmológico-ritual bastante generalizado na Amazônia indígena, onde, segundo Viveiros de Castro (1993, p. 186), "a predação do exterior surge como condição de produção do corpo social em sua dimensão local, como o elemento de construção das diferenças e dinamismos internos".

\section{Reciprocidade e vingança}

Desde os primeiros contatos, em fins dos anos 1960, foram os próprios Cinta-Larga que, meticulosamente, distinguiram o que lhes interessava em nossa cultura, quando "pegaram" os utensílios de metal e, logo, todos os demais bens e serviços ao seu alcance.

Talvez não seja preciso recordar que o conceito de escassez, tanto quanto o de utilidade, não corresponde a uma propriedade intrínseca aos meios técnicos, mas a uma "relação entre meios e fins" (Sahlins, 1972, p. 5). E como notou Sahlins (1979, p. 228), à razão utilitária ou prática contrapõe-se um cálculo propriamente simbólico ou significativo: "não há lógica material separada do interesse prático e o interesse prático do homem na produção é simbolicamente instaurado".

Do mesmo modo, a noção de reciprocidade, tantas vezes tomada como norma moral ou como sintaxe sociológica das economias ditas primitivas, cujos significados, entretanto, variam acentuadamente segundo as culturas e seus contextos. Atribuiu-se a Thurnwald (1916) o primeiro achado: entre os Banaro da Nova Guiné, as formas simétricas assumidas pelo pensamento nativo, tanto quanto as disposições institucionais e, em particular, os arranjos matrimoniais, ali expressariam um firme princípio de retribuição ("principle of requital") ou de reciprocidade social, análogo ao preceito arcaico da "retaliação do mesmo pelo mesmo” (p. 258). Desde então, a noção de reciprocidade alojou-se decididamente no discurso antropológico, a despeito de sua crescente imprecisão conceitual - de acordo com Gouldner (1960, p. 161), poucos conceitos seriam assim tão "obscuros e ambíguos".

Para Foucault (1985, p. 205), o fenômeno da troca envolveria, de imediato, o valor da coisa a ser trocada e a representação desse valor pelos parceiros. No pensamento ocidental, a discussão sobre a noção de reciprocidade remonta a Aristóteles (1987), na Ética a Nicômaco. Diante de uma equação em que duas relações simultâneas concorrem, a de equivalência entre as coisas dadas e recebidas e a de igualdade entre as pessoas que dão e recebem, o filósofo especificou a virtude como a proporção justa entre dar e receber, posto que se tratava de uma "disposição de caráter 
de quem dá e esta é relativa às suas posses" (p. 62). E como quem dá é superior a quem recebe, o "homem magnânimo" haveria de se equilibrar entre a vaidade e a humildade, entre a prodigalidade e a avareza.

Meio-termo não apenas com relação ao valor dos objetos transacionados, mas também acerca do "valor" das pessoas envolvidas. $\mathrm{Na}$ ética aristotélica, como se sabe, a justiça corresponde a uma virtude geométrica, capaz de atender a uma adequada proporção entre o todo e as partes, entre as coisas e as pessoas. Igualmente a reciprocidade, que tanto acarreta a disposição estratificada dos homens entre si (de status ou ordem social) quanto a equivalência comparativa dos objetos de que estes dispõem (o preço ou a medida comum). Uma relação binária e simétrica, que conjuga de maneira proporcional os indivíduos que trocam e as coisas que são trocadas, as leis sociais e as utilidades naturais. Porquanto, caso não fosse possível igualar artigos diversos entre si, não haveria associação entre as partes; e sem preços equivalentes, nem as trocas ou os vínculos sociais correspondentes.

Para além da exegese filosófica, as descobertas etnográficas e as notáveis contribuições teóricas à questão encarregaram-se de alargar consideravelmente esse escopo original. Todavia, haja vista que jamais se apartou completamente da proposição seminal de Aristóteles, não residiria na própria noção de reciprocidade uma refração da root metaphor do Ocidente, no sentido que Marilyn Strathern (1988) deu à expressão? Primeiro, a separação ontológica entre sujeitos e objetos da troca, que faz com que esta seja concebida como uma operação que comuta relações de propriedade entre pessoas tidas como indivisas - onde a regra de apropriação privada, de maneira contingente, associa coisas tidas como inertes a indivíduos tidos como autônomos. Segundo, o descolamento de uma esfera sociológica exclusiva, que privilegia o circuito humano em que se movimentam os bens materiais e não leva em conta os intercâmbios que se efetuam em, e entre, distintas dimensões cosmológicas (Latour, 1994). Por último, a prescrição moral que segrega a generosidade e a cooperação ao domínio da intimidade, enquanto vincula rigidamente a competição e a disjunção ao espaço público (Dilley, 1992).

Ora, para um universo no qual sobressai o estatuto relacional do predador e de sua presa, no qual as pessoas e seus pontos de vista não designam mais que graus ou posições variáveis (Viveiros de Castro, 1993; 1996), ocorre que os agentes da troca (os sujeitos) e os objetos da troca (as coisas), obviamente, não se distinguem a priori, ou não de maneira absoluta. Mas se pessoas e coisas não se separam em razão de suas naturezas próprias, então como pensá-las?

Parti pris, a noção de reciprocidade. Polanyi (1957a, p. 73) tomou-a como conceito genérico, em sua justa dimensão sociológica: "Reciprocidade de- manda adequação de resposta, e não igualdade matemática." A reciprocidade implicaria assim a mobilização do outro como sujeito, e não uma equação apenas entre os objetos da troca. Para Simmel ([1908] 1950, p. 387), antecipando-se à conhecida fórmula maussiana, todos os contatos entre seres humanos repousariam no "esquema de dar e retornar a equivalência" e, quando inviável sua aplicação estrita, então a gratidão apareceria como um suplemento que sedimenta o laço recíproco. A rigor, na opinião desse sociólogo, as dádivas e as permutas conservar-se-iam para sempre incomensuráveis: de um lado, a retribuição não é arbitrária, mas uma resposta motivada pela dádiva anterior que a precede (e por isso a dádiva inaugural assume um character indelebilis, porque é ela que engendra o sistema); de outro, a maior parte das trocas confronta coisas que, em si, mostram-se heterogêneas, e neste sentido a equivalência não seria mais que um cotejar, por referência a um sistema de valores convencional ou extrínseco.

Na mesma direção, Lefort ([1951] 1979) argumentou que a troca (ou a reciprocidade) compreende uma relação antitética do sujeito e de outrem, "um ato que separa os homens e os coloca frente a frente" e que deste modo lhes confere a sua própria condição de sujeito (p. 31). Com muito esmero, Lefort retomava os passos de Mauss e de Lévi-Strauss, que na troca avistaram os fundamentos da vida social:

Dar é tanto pôr outrem sob nossa dependência quanto nos pormos sob sua dependência ao aceitar a ideia de que devolverá o dom. Mas esta operação, esta iniciativa no dom supõe uma experiência primordial graças à qual cada um se sabe implicitamente vinculado ao outro; a ideia de que o dom deve ser restituído supõe que outrem é um outro eu que deve agir como eu; e este gesto em retorno deve me confirmar a verdade de meu próprio gesto, isto é, minha subjetividade. $\mathrm{O}$ dom é, assim, ao mesmo tempo o estabelecimento da diferença e a descoberta da similitude. Separo-me do outro e o situo defronte a mim dando a ele algo, mas esta oposição não se torna real a não ser quando o outro age da mesma forma e, por conseguinte, em certo sentido a suprime. [...] Não se dá para receber; dá-se para que o outro dê. (p. 33)

Como tudo isto, igualmente, convém à questão da vingança, assunto sabidamente crucial na etnologia ameríndia, resulta daí a interpretação do modelo da predação na mesma clave da reciprocidade. Pois, se não a reciprocidade, um ato capaz de implicar ou mobilizar outrem na condição de sujeito, então o quê? Ao examinar os temas da inimizade, do canibalismo e da afinidade e a praxis guerreira, Fausto (2001, p. 322-333) introduziu o conceito de "consumo produtivo", de talhe marxista, no intuito de tomar distância 
do clichê estruturalista (e maussiano) que assimilara a vingança e a guerra a modalidades de troca, tais quais relações simétricas entre inimigos declarados. Para o autor, a guerra ameríndia pertenceria antes à esfera produtiva, e não à do consumo, uma vez que a morte do inimigo fornece corpos, nomes e identidades, usados como princípios de estruturação social.

O ponto de partida de sua crítica, decerto, é a proposição de Lévi-Strauss ([1942] 1976) acerca do fenômeno da guerra entre os Tupinambá, a serviço dos ritos antropofágicos: uma modalidade particular de troca - de violência, de corpos, de vingança -, que as categorias nativas, de modo geral, designam como pagamento, retorno, equivalente, contrapartida ou compensação, termos também comuns à esfera econômica. Para Fausto, tal argumento privaria a guerra de sua dimensão política, ao mesmo tempo em que ignorava a "realidade fenomênica da vingança":

enquanto na troca de bens aquele que dá quer receber, na vindita o desejo se inverte e o matador não quer ser pago, nem está obrigado a receber o pagamento (isto é, sua própria morte). (p. 325)

Ora, o equívoco deste raciocínio está, precisamente, na suposição errônea de que o princípio de reciprocidade, como condição geral e apriorística da sociabilidade, nos termos postos por Simmel, Mauss e Lévi-Strauss, dentre outros, esteja confinado ao cálculo singelo das equivalências puras, à simetria tout court entre os que trocam ou aos valores e normas que motivam os sujeitos a dar, receber ou retribuir. Fora de questão, por isto, qualquer suspeita ou temor de uma morte indesejada (o que, a rigor, é uma incorreção etnográfica, ao menos para os orgulhosos cativos Tupinambá, cujo sacrifício no terreiro se lhes apresentava como honroso). Pois, antes de tudo, o que aciona o desejo de vingança é o rancor profundo por alguma morte que os inimigos infligiram ou mesmo a que, a força de projetá-la no futuro, aqueles vão infligir aos seus (Carneiro da Cunha \& Viveiros de Castro, 1985). E como as etiologias ameríndias creditam todo e cada óbito humano, em geral, a um ato de predação real ou suposto, disto resulta que as terminologias nativas, muitas vezes, designam-no como uma dívida a cobrar ou, mais propriamente, uma compensação ou uma contrapartida. ${ }^{3}$ Entre os Cinta-Larga, em particular, não há óbito que não se converta, de imediato, em acusação de homicídio e em motivo de ameaças, ainda que dissimuladas. Mesmo nos casos de doença ou acidente, eles atribuem a causa mortis ora a envenenamento, ora a agressão de seres sobrenaturais maléficos, os espíritos pavo.
O que importa, enfim, é que na vingança, tal como na reciprocidade, reconhece-se um mecanismo que mobiliza um oponente, que o demanda, de maneira incisiva, sob a condição de sujeito de uma relação. O ódio e o desejo de retaliação é o que significam as vinditas intermináveis, que tomam corpo em expedições contra inimigos reais ou supostos, contra acusados de toda a sorte de agressões, mortes e feitiços...

Nas últimas duas décadas, como já disse, os Cinta-Larga envolveram-se no processo de extração dos recursos naturais existentes em suas terras, principalmente madeira, ouro e diamante. Esse comércio e seus resultados, decerto, não subsistiriam num espaço privativo ou desconectado de outras atividades produtivas, instâncias políticas ou esquemas rituais. No entanto, retomando aqui uma sugestão metodológica de Sahlins (1979, p. 232), "o esquema cultural é variadamente flexionado por um ponto dominante de produção simbólica, que fornece o código principal das outras relações e atividades". Este é, por hipótese, o lugar ocupado pela lógica da predação canibal.

\section{Da predação ao comércio}

Trata-se, a rigor, de uma economia política - a produção e o consumo de bens e serviços no contexto de uma ordem social orientada por um princípio de reciprocidade assimétrica. No plano interno, um fluxo contínuo que integra as demandas do chefe da aldeia e de seus moradores; e, no contexto das relações exteriores, uma espécie de contabilidade qualitativa, que se recompõe a cada momento ao sabor de acordos e dívidas que os vinculam a uma gama variegada de atores e instâncias sociais - outros chefes, associações indígenas, órgãos públicos, entidades civis, madeireiros, garimpeiros, comerciantes ou civilizados em geral.

Nada indica, por outro lado, que eles se sirvam da divisão que Cora Du Bois (1936, p. 50) apontou entre os Tolowa-Tututni da costa norte da Califórnia, de uma "economia de prestígio" (a aquisição ou o dispêndio de bens valiosos ou luxuosos, que sinalizam prerrogativas e status desiguais) e uma "economia de subsistência" (a produção e o consumo de bens úteis que asseguram a existência). Ao contrário, entre os Cinta-Larga, prestígio e subsistência não se dissociam jamais, nem nas lides comezinhas nem nos atos solenes, nem na conduta dos chefes ou dos comuns. A despeito das diferenças funcionais entre estes e aqueles, observa-se ali um único padrão ético, ajuizado por uma mesma sentença moral, que tanto 
desaprova a mesquinhez com relação às coisas quanto o ciúme excessivo entre as pessoas.

No que concerne às atividades econômicas dos chefes nas chamadas "sociedades primitivas", longe de apenas ostentação ou dissipação suntuosa, por toda parte os relatos etnográficos enfatizam que o prestígio e o poder decorrem, sobretudo, da generosidade, da doação e da partilha de riquezas acumuladas - não para consumo próprio, mas sim de outrem (Sahlins, 1963). O que demonstraria, em todos os casos inventariados, que as atividades e as obrigações econômicas, de variadas maneiras, estão postas a serviço e ao abrigo das funções políticas tout court.

Com igual desenvoltura, para consolidar ou estender seu prestígio e sua influência sobre um número crescente de seguidores, o zapivaj (dono da casa) cinta-larga direciona seus esforços no sentido de angariar mais recursos e mais benefícios, tanto os que provêm da produção interna quanto os capturados alhures. Daí que a eventual rivalidade entre adversários renitentes, que se evidencia na tensão latente e nos conflitos eventuais nos planos político e econômico, se por um lado restringe os movimentos e a ousadia dos mais ambiciosos, por outro, concorre para uma definição ad hoc dos contornos que atualizam os grupos locais.

À primeira vista, as qualidades necessárias a um líder cinta-larga não são outras que aquelas típicas do panorama sul-americano (Lowie, 1948; Clastres, 1978; 1982). Um zapivaj, por isso, desdenhou nestes termos a conduta inadequada de um outro: preguiçoso, não fazia roça, não caçava e sua esposa não trabalhava. O destempero, as altercações e a mesquinhez, da mesma maneira, são defeitos graves que suscitam censuras e a indisposição dos aldeãos. E, ainda, críticas mais severas e generalizadas aos atuais chefes: "Só corta madeira. Não ajuda [a comunidade]!" - segundo o informante, um dos líderes não cumprira a promessa de reformar a casa na cidade de Aripuanã, onde doentes e passantes abrigavam-se. Serão estas, então, a vontade firme, a retórica, a generosidade, a comida e a casa, além das mulheres, as disposições subjetivas e materiais da função política?

Entre os Cinta-Larga, em geral, as atividades coletivas são organizadas por quem a propôs, por quem as iniciou ou tomou-lhes a dianteira. A este, denominam bexipo, o que está à frente (do "caminho", be). Posição de destaque em variados contextos, a que se chega por vontade própria ou de outrem - caçadas, pescarias, expedições de coleta de mel e castanha e de matérias-primas, visitas a outras aldeias, excursões à cidade para adquirir equipamentos ou mercadorias. O ponto de partida, desde logo, é a manifestação pú- blica de uma vontade individual, ${ }^{4}$ capaz de conjugar e dar forma às ações coletivas. Entre o bexipo e seus companheiros, conecta-os um vínculo de cunho funcional, ainda que de curta duração. Comum a muitas sociedades amazônicas, constitui um tipo de ordenamento característico e abrangente para as tarefas econômicas. Do teneãmõ araweté, por exemplo, diz Viveiros de Castro (1986, p. 301-302) que sem ele as ações solidárias seriam impensáveis, e nem mesmo haveria uma aldeia.

De forma análoga, a posição mais permanente do zapivaj determinava-se, tradicionalmente, pela relação metonímica que vinculava um dono à sua casa e pela função intrinsecamente alimentar que ele cumpria (roças, festas etc.). Diferenciava-se dos demais moradores, no entanto, pela escala de suas obrigações alimentares e a sua dimensão política. Aspectos também destacados pelos antigos Salamãi (de língua tupimondé), entrevistados pela linguista Becker-Donner (1955: 293): o chefe "se preocupa para que todos tenham alimentação e para que tudo esteja em ordem".

Decerto, os bens ali não circulam numa única direção: em quase todos os momentos formais e nas atividades cotidianas é a função de zapivaj que se destaca. Nas casas comunais, de formato oblongo, a família do zapivaj ocupava, comodamente, um dos espaços laterais e, nas aldeias atuais, em regra, é dele a casa mais ampla e melhor apetrechada. Sem motivos aparentes que não o regalo, davam-lhe taquaras ou flechas e outros sinais de reconhecimento; os caçadores estimavam favorecê-lo, seja com uma parte da caça ou na partilha da carne cozida; e os chefes de família cuidavam para que fosse o primeiro dentre os convidados a beber chicha.

Se é verdade que os cuidados do zapivaj, em favor do bem-estar dos moradores de sua aldeia, trazem aqueles traços entrevistos na filosofia política ameríndia (o apaziguamento dos conflitos internos, a iniciativa guerreira, a moradia, a fartura alimentar e as festas), disto não se segue, todavia, que se possa compreendêlo, a ele e a sua função, como algo "exterior à estrutura do grupo", como pretendeu Clastres (1978). Ao contrário, na expressão pitoresca de um informante, o zapivaj está ali como "o bicho da goiaba, o bichão". Em outras palavras, o dispositivo político enraíza-se na própria ordem social, ao mesmo tempo em que determina os fluxos de troca que ela instaura.

Moradia e alimentação, assim, são os principais preceitos da função de chefia entre os Cinta-Larga. A construção de uma casa (zap), para todos os efeitos, é a primeira providência de quem é ou se pretende um zapivaj. Para isso, ele requisita o auxílio de parentes e outros colaboradores, os condôminos da empreita- 
da em curso. Futuros usuários que, não obstante, são recompensados pelos serviços que então prestam ao zapivaj, normalmente mediante dádivas alimentares: o solicitante prepara um banquete para as famílias dos colaboradores e demais agregados, ou então oferece alimentos em espécie. Na atualidade, a construção de casas de madeira é não apenas um estratagema para atrair novas famílias à sua aldeia, mas uma demanda assídua dos moradores ao zapivaj. O que faz da "política habitacional", entre eles, um dos principais tópicos da pauta de negociação com madeireiros e agentes públicos, um foco primário de querelas e de pressões - para a aquisição de material de construção, a contratação de carpinteiros etc.

Mas, à razão política, hoje não bastam a construção da casa, a abertura de roças e a promoção de festas. Cada vez mais, as disputas de poder condensam-se a instâncias de negociação e nos mecanismos de controle dos recursos financeiros auferidos com as atividades garimpeiras e madeireiras. Pois, agora, o exercício da chefia requer umas tantas condições adicionais, dentre elas a posse de carros, camionetes e caminhões que servem ao vaivém interminável da aldeia à cidade, de moradores - para compras, aposentadorias a receber, atendimentos médicos ou simples lazer - e de mercadorias e demais produtos de consumo regular.

Cena comum nas ruas de cidades próximas e nas estradas da região, a passagem de camionetes cinta-larga, com a carroceria lotada de adultos e crianças e toda sorte de caixas, sacos e trastes. A saída para a cidade e o retorno à aldeia, invariavelmente, avivam um rebuliço de interessados ao redor do veículo, sem que o motorista ou o responsável pela viagem esboce qualquer objeção à quantidade de pessoas ou à carga. ${ }^{5}$ $\mathrm{E}$ os que vão, muitas vezes, levam pedidos dos que ficam: ao retornar, o zapivaj ou o motorista entrega as encomendas, com a etiqueta discreta que lhe convém: a pasta dental para um, alguns quilos de carne que um outro divide com o pai, uma rede ou coberta que um terceiro carrega embrulhada. Pequenas coisas, antes agrados que necessidades prementes, a exemplo de uma garrafa de refrigerante que se bebe de pronto.

\section{Um modo de consumo}

No cumprimento de suas tarefas, normalmente, o zapivaj nomeia auxiliares diretos - um irmão, um filho ou um genro. Os grupos locais mais numerosos, então, podem comportar um staff político especializa- do, composto por um ou dois coadjuvantes do zapivaj. Estes "mandam as pessoas trabalhar", razão pela qual, justamente, são denominados poemãkira. Faculta-lhes, inclusive, certa expectativa de sucessão, em caso de falecimento ou abdicação do principal. Função análoga a que, na mitologia cinta-larga, cumpre o ajudante Kot diante do demiurgo Gora - estes personagens e os episódios de que são protagonistas, obviamente, remetem ao conhecido tema mítico dos gêmeos das tradições tupis. ${ }^{6}$ Temos aqui os elementos básicos para o modelo de vida aldeã: de um lado, a função Gora, que caracteriza o anfitrião doador de alimentos, generoso e hospitaleiro, cujos atributos tradicionais são a casa, a roça e a festa; e, de outro, a função Kot, cristalizada no ajudante de ordens, bem como os moradores que prestam "ajuda" ou serviços ao dono de casa. Na tradução desses conceitos para o português regional, o primeiro é o "patrão" e os demais, seus "peões" - termos que assinalam o vínculo entre fazendeiros e trabalhadores braçais das imediações. De maneira que, desta feita no plano sociológico, reencontramos assim o esquema de reciprocidade ritual da festa, no qual sobressai a troca de alimentos por bens e "serviços", dados e recebidos por sujeitos assimetricamente dispostos, o anfitrião e seus convidados (Dal Poz, 1991).

Durante alguns meses em 1997, funcionou na aldeia Taquaral uma cozinha da "comunidade", onde se conjugavam as atividades produtivas à distribuição alimentar: os moradores trabalhavam nas tarefas indicadas pelo zapivaj; em contrapartida, uma ex-esposa deste preparava-lhes as refeições. Logo desativada, a "cozinha" foi substituída por um "armazém": um barracão onde estocavam mercadorias (principalmente, alimentos e material de limpeza), que os moradores retiravam livremente, à medida de suas necessidades domésticas.

Nos anos seguintes, o armazém funcionou regularmente, ainda que seu estoque tenha sofrido fortes oscilações. As compras eram realizadas no supermercado Cerejeiras, na cidade de Aripuanã, por meio de requisições autorizadas pelos madeireiros Schimanski e Balbinotti. Do ponto de vista dos moradores da aldeia, as dívidas que se acumulavam no supermercado e nos demais estabelecimentos comerciais que forneciam aos Cinta-Larga, dívidas que cresciam especialmente na estação chuvosa quando se interrompem as tarefas de extração, eram de responsabilidade exclusiva do zapivaj e seu filho, porque eram eles, justamente, que intermediavam a venda de madeira.

De acordo com Junqueira (1984/1985, p. 231), os Cinta-Larga da Serra Morena iniciaram em 1981

5 O excesso de peso e as estradas precárias comprometem a vida útil e provocam seguidos problemas mecânicos que encarecem a manutenção dos veículos. Por esta razão, mas também por imperícia no volante e alcoolismo, os acidentes são frequentes e, nos últimos quinze anos, já respondem por um número elevado de óbitos.

6 Para os Cinta-Larga, Gora criou seu ajudante Kot justamente para que o auxiliasse nas tarefas pesadas, as que exigiam o uso de força física. 
a extração de borracha com o objetivo de conseguir dinheiro para adquirir mercadorias de consumo. Os resultados, porém, nunca foram animadores. Já então, alguns artigos artesanais eram negociados ocasionalmente com funcionários da Funai ou regionais, igualmente com retorno inexpressivo. Foi somente a exploração comercial de madeira e a "liberação" do garimpo Ouro Preto, na área Aripuanã, a partir de meados da década de 1980, que proporcionaram aos Cinta-Larga mercadorias e dinheiro em abundância.

\section{Novas alianças}

Entre outros aspectos a observar, a função de zapivaj ampliou seu alcance político e econômico, incorporando novas atribuições e obrigações, inclusive as que, mal ou bem, a Funai antes exercia. Em poucos anos, praticamente todos os líderes indígenas de Rondônia e Mato Grosso se envolveram com madeireiras para, em troca do mogno, do cedro e da cerejeira, adquirir veículos, abrir estradas, derrubar e plantar roças mecanizadas, instalar energia e antenas parabólicas nos postos e aldeias, comprar casas nas cidades vizinhas etc.

Por muitos anos, a maior parte da madeira extraída nos municípios de Juína e Aripuanã (MT) originou-se das terras indígenas. A Funai, o Ibama e a Secretaria de Fazenda do Estado, mais recentemente, esboçaram certas medidas para impedir o aliciamento de lideranças indígenas, os danos ambientais e o esbulho do patrimônio público. Até então, as firmas madeireiras atuavam praticamente impunes: sem planos de manejo ou medidas de controle ambiental, nunca lhes faltou, contudo, autorizações e guias fiscais para o transporte, o comércio interestadual e até a exportação de tábuas e toras dali extraídas.

Em 1989, as lideranças cinta-larga da área Roosevelt, na presença de convidados de todas as demais áreas, reuniram-se em Riozinho (Cacoal (RO)) e fundaram a associação Pamaré ("o que é nosso", numa tradução livre), com o objetivo precípuo de organizar a venda de madeira - o primeiro secretário, não por acaso, era um zaryj (civilizado) indicado pelos madeireiros. Alguns jovens, antes empregados nos serviços dos postos e nas expedições da Funai, ocupavam agora o lugar deixado pelo órgão indigenista - lugar estrutural, num certo sentido -, articulando simultaneamente a "assistência" e o "controle" político das áreas indígenas. Expressão dessas mudanças no plano geográfico foi o apossamento do espaço físico e das instalações da Funai no distrito de Riozinho. Ali os Cinta-Larga instalaram a sede da associação Pamaré, e logo alguns compraram casas de funcionários (com a desativação da sede do parque do Aripuanã, a administração regional da Funai transferiu-se para Cacoal), transformando o distrito praticamente numa “aldeia urbana” (Hargreaves, 1993).

No ano seguinte, os líderes da área Serra Morena e adjacências, por sua vez, fundaram a associação Norte-Matogrossense, com sede em Juína (MT), com as mesmas finalidades da anterior. Reinterpretando assim a função zapivaj, os Cinta-Larga buscavam se posicionar naquele contexto regional em constante transformação. De certo modo, seguiam os passos que a própria Funai intentara, voltando-se para a comercialização de um recurso natural que escasseava nos latifúndios e nas fazendas do entorno. Tal como se passara entre os demais Tupis-Mondés - os Suruis, os Zorós e os Gaviões -, a política da madeira espraiou-se por postos e aldeias, até alcançar toda a população cinta-larga, quando os recursos financeiros obtidos se tornaram o principal instrumento para a persuasão e a manutenção de correligionários. Os que primeiro dominaram o processo logo se puseram à disposição para "ensinar" e "ajudar" os demais, de modo a não serem "enganados" nos negócios, o que facilitou a consecução de inúmeros acordos entre líderes locais e empresários madeireiros já conhecidos.

$\mathrm{Na}$ área Aripuanã, a extração teve início por volta de 1990, com o declínio do garimpo Ouro Preto, que, havia alguns anos, os Cinta-Larga controlavam diretamente. Os acordos iniciais foram promovidos pelo zapivaj do posto Rio Preto, com a ajuda de um Cinta-Larga da área Roosevelt. Além da abertura da estrada ligando o posto à cidade de Aripuanã e a construção de uma ou outra casa, os líderes locais apresentavam requisições quinzenais de mercadorias, através de ofícios que o próprio chefe da Funai datilografava.

Após a conclusão da estrada de acesso, em 1993, os negócios prosseguiram. Aos Enawenes-Nawes que os visitaram em 2001, os líderes da aldeia Taquaral declararam que se "acostumaram" a comprar comida, roupas etc.; agora, as mulheres não faziam mais tantos colares e eles estavam "perdendo a tradição, vivendo como os brancos”. Acerca do saldo da exploração madeireira, sobrava-lhes bem pouco no período inicial, quando eram "ajudados" por líderes de outras áreas (Serra Morena e Roosevelt, principalmente), os quais faziam os acertos com os madeireiros e ficavam com a maior parte do dinheiro arrecadado. Aqueles lhes diziam: "Vocês não sabem. Eu sei falar, sei fazer negócios..." Depois que os afastaram e assumiram as negociações, passaram então a dispor de recursos suficientes para as despesas locais. Os benefícios colhidos com o comércio de madeira naquela safra: novas casas, gerador e rede de luz, quatro antenas parabólicas, freezer e geladeiras, dez cabeças de gado, uma camionete Toyota nova, uma casa na cidade e uma pista de pouso na aldeia.

Entretanto, ao sabor das demandas e dos interesses ocasionais em jogo, as relações entre líderes cinta- 
-larga, intermediários e madeireiros oscilavam vivamente, registrando-se inúmeros desentendimentos, suspeitas, ameaças e mesmo agressões. Por exemplo, em abril de 1994, a chegada inesperada em Aripuanã de uma turma de homens da aldeia Taquaral, todos pintados e armados, no encalço de madeireiros a quem acusavam de roubo de madeira - sequestraram dois caminhões, exigindo do próprio delegado de polícia que os prendesse.

Sob o ponto de vista local, por conseguinte, a extração de madeira constitui um campo de disputas políticas, que tanto serve às pretensões econômicas de um zapivaj sobre determinado território quanto reafirma a sua autoridade sobre um grupo de corresidentes e de aliados. Entre outras tantas, recolhi de um deles esta acusação enfática contra outro, embasada na primazia do poder político sobre a ordem econômica: "Ele não é chefe. Por que madeireiro pensa que ele é chefe? Libera madeira, libera garimpeiro...?"

De um plano mais geral, com a entrada em cena da mediação exercida pelas associações cinta-larga, a atividade madeireira revelou-se um processo que replicava os contornos sociopolíticos dos antigos agrupamentos de aldeias. ${ }^{7}$ As aldeias próximas a Aripuanã estreitaram seus vínculos com a associação Norte-Matogrossense, de Juína, e, assim como as aldeias da Serra Morena e imediações, pagavam-lhe a percentagem de $15 \%$ do que arrecadavam com a venda de madeira. Já a aldeia Cachoeirinha, na seção oeste da área Aripuanã, filiou-se à associação Pamaré, sediada em Rondônia, para a qual contribuía com $20 \%$ do que obtinha. Junto com ela, todas as aldeias da área Roosevelt e do rio Capitão Cardoso, onde as árvores de valor comercial restantes estavam sendo aproveitadas por meio de "catação". ${ }^{8}$ E, por sua vez, para não pagar nem a uns nem a outros, o zapivaj do posto Tenente Marques, no parque do Aripuanã, fundou a sua própria associação, denominada Paerenã (cuja tradução seria "os que trabalham").

Um ponto crítico na comercialização da madeira, certamente, é a falta de controle das quantidades extraídas e transportadas, mediante a cubagem e o romaneio das toras. Sem instrumentos ou mecanismos para conferir as espécies e os volumes nas "esplanadas",9 a aldeia Taquaral obrigava-se a confiar na medição realizada pelos próprios madeireiros no pátio das serrarias, avalizada por um medidor contratado pelos Cinta-Larga, mas pouco confiável.

\section{Dinheiro e troca}

Conquanto uma forma versátil para satisfazer o consumo em expansão e cumprir as obrigações mútuas, cuja finalidade os Cinta-Larga rapidamente assimilaram, o uso do dinheiro não parece ter resultado, até agora, em um processo de precificação dos bens e serviços que circulam internamente. Significa dizer que, neste caso, a monetarização não se fez acompanhar de uma tendência à mercantilização ("commoditization”) das relações sociais (Kopytoff, 1986; Parry \& Bloch, 1989). Embora pouco estudado no panorama sul-americano, tudo indica que o processo de "endinheiramento" de populações indígenas não ocasiona, necessariamente, a incorporação de formas e valores mercadológicos que, entre nós, encontramse associados ao uso e ao discurso do dinheiro. Entre os Xikrins do Bacajá, por exemplo, Fisher (2000, p. 132) observou que, para a comunidade aldeã, o "valor de troca dos bens" resultava, sobretudo, de "obrigações" oriundas da "participação em atividades conjuntas sem referência ao valor de mercado dos recursos naturais" (madeira e ouro, em sua maior parte); enquanto os chefes, à frente de transações com mineradoras e madeireiras, não podiam ignorar as pressões e os constrangimentos tanto de seus patrícios quanto de garimpeiros, madeireiras e agentes públicos. Entre os Xikrins do Cateté, por sua vez, ao comparálo aos conhecimentos xamânicos, Gordon (2006, p. 278) caracterizou o dinheiro como um instrumento poderoso capaz de operar transformações que subsumiam "uma gama extremamente múltipla de outros conhecimentos, saberes e técnicas", sobretudo de nosso mundo industrial.

Em outubro de 1987, acompanhei uma família cinta-larga (o marido, a esposa e duas crianças) nas ruas de Aripuanã: excitada, mas não sem cautela, exercitava então as novas oportunidades que a reabertura do garimpo Ouro Preto introduzira. O marido, um homem sóbrio que se equilibrava entre os novos hábitos e a vida tradicional (havia sido um dos últi-

7 Os Cinta-Larga dividiam-se, tradicionalmente, em três grandes agrupamentos: ao sul, nas redondezas dos rios Tenente Marques e Eugênia, as aldeias dos Paabiyj ("os de cima"), ou Obiey ("das cabeceiras"); em direção ao norte, próximo à confluência do rio Capitão Cardoso com o rio Roosevelt, moravam os Paabiryj ("os do meio"); e, adiante, nos rios Vermelho, Amarelo e Branco, os Paepiyj ("os de baixo"). Tal classificação espacial tomava por eixo a direção em que correm as águas dos rios Aripuanã e Roosevelt, os quais, neste trecho, seguem quase paralelos do sul ao norte. Através das categorias alto/médio/baixo, de uma geografia orientada em declive, distinguiam os agrupamentos uns em relação aos outros.

8 Catação é o processo de aproveitamento de áreas já exploradas, quando percorrem estradas, ramais e carreadores, abertos em ocasiões anteriores, para localizar e extrair árvores isoladas ou esquecidas.

9 Esplanadas são locais abertos na floresta, que servem para empilhar as toras que serão depois transportadas em caminhões. 
mos a abandonar sua aldeia para juntar-se aos demais no posto), buscava atento as lojas onde fazer compras, após vender os 3,9 gramas de ouro que trouxera. $\mathrm{Na}$ loja de um conhecido comprador de outro, recebeu 780 cruzados pelo grama; dali, foi ao banco trocar o cheque. Quando saiu, o marido conferiu o dinheiro recebido, guardando-o então na carteira. Mas logo, um pouco embaraçado, virou-se e perguntou-me se eu queria algumas das cédulas, apontando-as - um gesto cujo significado, decerto, estendia ao dinheiro a etiqueta de generosidade e partilha que convém às relações sob o crivo da sociabilidade.

Segundo Marx ([1867] 1983, p. 55-70), o dinheiro desempenharia o papel de "equivalente geral dentro do mundo das mercadorias", como "uma forma do valor em si". Polanyi (1957b, p. 264-266), na mesma direção, adverte que, nas economias de mercado, o dinheiro define-se como um "meio de troca indireta", que serve para pagamento ou quitação de obrigações e como padrão de valor (pois exprime diferenças qualitativas em termos de quantidades divisíveis). A esta concepção moderna, Polanyi atribuiu o rótulo de "all-purpose money", para distingui-la de uma definição substantiva, que focalizaria os usos específicos de objetos quantificáveis em diferentes situações e sociedades. Na opinião de Parry e Bloch (1989, p. 12), os antropólogos teriam aceitado de maneira acrítica a noção dominante no pensamento ocidental de que a moeda representa sempre "um poder intrinsecamente revolucionário que inexoravelmente subverte a economia moral de sociedades 'tradicionais" quando interagem com o mercado capitalista.

Quanto à função que o dinheiro cumpre entre os civilizados, não parece que os Cinta-Larga tenham tardado a compreendê-la. Recordo-me das perguntas insistentes, ainda nos idos de 1980, sobre os gestos que acompanham a entrega de cédulas ao comerciante ou ao balconista - então, apenas praticavam com notas de um ou dois cruzeiros que guardavam amarfanhadas junto a penas, pedaços de cerol e outros petrechos. Difícil, então, foi explicar-lhes o processo inflacionário que corroia a economia brasileira e alterava continuamente a quantidade de notas necessárias para a compra dos utensílios desejados. Mas, já em novembro de 1982, entrementes, presenciei uma demorada conversa acerca do valor das cédulas, dos preços das mercadorias (avaliados através de categorias como "caro" e "barato") e as lojas onde se vendia mais em conta. Com a retomada do garimpo Ouro Preto, enfim, acostumaram-se aos pagamentos em cheque e a guardar dinheiro em contas bancárias.

Entre os Cinta-Larga, todavia, a ética das trocas não se subordina ao valor relativo de bens e serviços, senão ao contexto social em que ocorrem. Porquanto, até há pouco, cumpriam-se indistintamente as obrigações recíprocas dando-se flechas e colares ou ofer- tando alimentos. Signos de sociabilidade, com efeito, os artefatos e a comida apareciam, dentre outras ocasiões, na partilha doméstica entre familiares, na retribuição pelo auxílio na construção da casa ou na faina agrícola, na permuta ritual nas festas, no preço e no serviço da noiva e na indenização por homicídios.

No quadro atual, não resta dúvida, o dinheiro vem cumprindo o papel de dádiva por excelência, condição sob a qual circula através de uma rede difusa de relações de várias ordens. Os exemplos, a seguir, ilustram alguns aspectos desta questão.

$\mathrm{Na}$ casa citadina de um zapivaj, em Aripuanã, observei-o entregando a uma filha por copaternidade uma nota de 50 reais, ao passo que ao marido dela, simultaneamente filho do irmão e irmão por copaternidade, a quem devia uma parcela do acerto com o madeireiro comum, pagou-lhe 100 reais. Em seguida, o marido passou uma das notas de 50 reais ao filho; este saiu de bicicleta, decidido a comprar cinco marmitas para todos. Como o restaurante estava fechado, em lugar da comida retornou com um aparelho walkman colorido, pelo qual pagou 30 reais. Devolveu o troco ao pai e, contente, pôs então o aparelho a funcionar.

A cooperação para a derrubada e o plantio da roça, assim como outros serviços semelhantes, são hoje remunerados monetariamente, mesmo quando o auxiliar é um genro ou um pai classificatório. Cada um dos quatro homens que trabalharam na limpeza das capoeiras na aldeia Taquaral, em 1999, recebeu 300 reais do zapivaj. Quando lhe indaguei sobre esses pagamentos, a resposta surpreendeu-me: antigamente o zapivaj também pagava aos que roçavam e derrubavam, dando-lhes flechas e colares ou mesmo comida; e, ainda, quando se encerrava a temporada agrícola, comemoravam com uma festa - da mesma maneira que, prosseguiu ele, também com flechas e colares, pagava-se a mulher recebida em casamento...

É bem verdade que o processo de monetarização acentuou-se, sobretudo, naqueles encargos diretamente atrelados à comercialização dos recursos naturais. No posto Rio Preto, em setembro de 1998, assim, um informante reclamou de seu próprio irmão, que lhe devia 500 reais por cinco meses de trabalho em pesquisa de madeira. E também, ao lado do pagamento de serviços entre parentes, houve casos de compra e venda de bens.

A cooperação e os acordos, de todo modo, nem sempre garantem um remuneração a contento - motivando aqui e ali queixas, nem sempre ostensivas. Numa grota próxima ao posto Rio Preto, um rapaz garimpou duas pepitas grandes, num total de quinhentos gramas. Alguns o haviam ajudado a desbastar o barranco, a carregar as pedras etc., mas ele "não pagou ninguém"; ao invés, lançou-lhes uma proposta tentadora: "Vou comprar Toyota. Concorda?". Para isso, precisava ajuntar ao menos um quilo de ouro; 
porém, como nada mais encontrou, todo o dinheiro obtido na venda das pepitas esvaiu-se, "comendo e bebendo" e pagando prostitutas em suas andanças pela cidade - segundo um dos colaboradores.

Afora a venda de madeira e o garimpo, cujos recursos são apropriados pelo zapivaj e seus prepostos e intermediários, não há muitas outras fontes de renda monetária. Dentre elas, a função de motorista, a pesquisa de madeira, a associação com garimpeiros e a prestação de serviços ao zapivaj são as mais comuns. Todavia, homens mais velhos e mesmo jovens lamentam-se constantemente de sua falta: "dinheiro kala", dizia um, desejoso de viajar para Juína; "lá não dá para ganhar dinheiro", argumentava outro, que não acompanhou a esposa na visita à aldeia do irmão do pai dela; e "lá não tem serviço", comentou um terceiro, que abandonou a aldeia onde morava a esposa para "arrumar" trabalho no posto Rio Preto.

Por sua vez, a aposentadoria que os mais idosos recebem mensalmente, através do convênio entre o Instituto Nacional de Previdência Social e a Funai, embora acanhada, representa uma fonte de ingresso perene. Em abril de 1998, uma aposentada queixouse porque não conseguira comprar uma rede e um facão com o dinheiro daquele mês. Explicaram-me então que, na vez anterior, ela recebera três meses atrasados e, agora, apenas 120 reais - dos quais gastou mais de 80 reais em alimentos e pequenas coisas. Em abril de 1999, outro aposentado comentou que comprara pouco com o dinheiro da aposentadoria (três pacotes de arroz, um pacote de feijão e fósforos), pois tivera de pagar dívidas anteriores que assumira junto a estabelecimentos comerciais: "Pagar conta. Mãtere po ma'â" ("já peguei coisas antes"). Além das contas acumuladas, algumas vezes os próprios filhos ou outros agnatos apossam-se do dinheiro dos mais velhos para atender seus próprios interesses de consumo.

Nas palavras do zapivaj da aldeia Capivara, no parque do Aripuanã, o consumo de mercadorias e o uso de recursos financeiros seriam uma consequência das relações com a nossa sociedade:

Nós vivíamos bem, antigamente. Vocês [civilizados] procuraram a gente, fizeram contato. Nós aprendemos com vocês a usar roupa, camisa, sapato, boné, a comer sal, arroz... Agora precisa. Era melhor acabar a Funai, a Funai não faz nada, só atrapalha o nosso serviço [venda de madeira e garimpo].

Do ponto de vista da ideologia nativa, a procura de dinheiro justifica-se como a maneira de "se virar" sob as condições hodiernas. Não há aqui evidência ou intenção de acumulação de riqueza, sequer algum projeto de longo prazo. Tão-somente, o propósito de conseguir dinheiro para os itens de consumo diário - as despesas com roupa, utensílios, alimentação, ca- sas de madeira, gerador de energia, antena parabólica, televisão, veículo, combustível, hotel e inumeráveis outros gastos -, em sua maioria, itens considerados imprescindíveis para o atual modo de vida. Não se ignora, todavia, as consequências de uma conduta tida por alguns como insensata: o dinheiro está sendo gasto rapidamente, e apenas para o consumo imediato; quando a madeira se esgotar, dizem eles, nada mais teriam "de valor", nem o dinheiro nas contas bancárias. Acerca deste ponto, um informante assim avaliou as alternativas de "pegar dinheiro":

Nós precisamos de plantação [de cunho comercial]. Primeiro tocamos garimpo. Depois tirar madeira. Madeira quase acabou, já acabou. Como é que vamos se virar? Fazer plantação [é uma solução].

Com efeito, no período da entressafra da madeira não lhes resta, em geral, senão a alternativa de alienar os bens adquiridos (espingarda, revólver, televisão, motosserra, carro etc.). Um informante, com mordaz ironia, adjetivou um importante zapivaj de "viciado em carne", devido aos péssimos negócios que fazia para comprar comida: vendeu um motor de draga por 250 reais e uma pistola 765 por apenas 150 reais (havia pago, há pouco, mais de mil reais para adquiri-la). E quando se via sem nada para alienar, aproximava-se de um conhecido na cidade para lamentar a falta de carne e pedia-lhe um empréstimo: "Eu tenho madeira, eu tenho ouro. Depois vendo e pago." Comprava então cinco quilos de carne, devorados imediatamente no almoço - mandava a esposa fritar bifes e cozinhar outro tanto, fazia churrasquinho e comia com pão... E, na hora do jantar, estava outra vez com o mesmo problema: "Não tem carne!", exclamava.

O dinheiro, indubitavelmente, é o tema que hoje mais interessa a jovens e adultos. Do vocabulário para descrever as trocas, destaca-se a intenção do sujeito que faz a entrega de algo a alguém: o verbo nõ significa "dar"; vepinõ, "pagar" ou "retribuir"; e vepika, "vingar-se" ou "descontar" (causando a morte, castigando ou apreendendo algo). Mas "receber" e "pegar" são designados por um único verbo, ma'ã - da mesma maneira, o ato de "receber" e de "pegar" dinheiro. Para que se entenda a semântica do endinheiramento que desponta na sociedade cinta-larga, a seguinte comparação me parece ilustrativa: se a expressão norte-americana "to make money" deriva seus significados do mundo do trabalho e da produção e a brasileira "ganhar dinheiro", do universo lúdico da sorte e do azar, então o mote cinta-larga "pegar dinheiro" denotaria evidentemente a predação. Significa dizer a forma de ação do predador ao tomar para si a presa desejada. O que exige, naturalmente, não só uma atenção bem treinada, mas também a habilidade para explorar novas circunstâncias e novas oportunidades. 
Acrescento, a seguir, alguns exemplos e comentários para melhor informar tais contextos.

Sob vários aspectos, ao menos no ideário masculino, é como se o dinheiro estivesse no lugar antes ocupado pela caça aos animais, o assunto preferido nas rodas masculinas e, inclusive, objeto de devaneios oníricos. Quando sonhou com ouro, alguém me disse de manhã que era sinal de dinheiro, motivado talvez pelo convite para garimpar que um outro lhe endereçara. E, em agosto de 1998, no posto Rio Preto, registraram-se diálogos assíduos em torno do desejo e da necessidade de conseguir dinheiro, nos quais "dinheiro ma'ã" era a expressão mais constante. Numa noite, um homem pôs-se a avaliar as opções ao seu alcance para forçar o madeireiro a lhe pagar o trabalho na pesquisa de madeira - ou segurar a espingarda calibre 20 ou falar com o zapivaj com quem o madeireiro trabalhava. Por sua vez, um outro queria 150 reais para comprar roupas novas - achava que as suas já estavam velhas - e por isso lembrou-se de um "mogno sadio" que localizara dias antes, uma possível solução para a falta de dinheiro.

Enquanto supervisionava a despescagem semanal dos garimpeiros, esperando receber a sua parte pelos dias que trabalhou (no posto Rio Preto, em novembro de 1998), um informante comentou as formas de obtenção e de uso de dinheiro por seus patrícios (de sua parte, se conseguisse "pegar dinheiro", pretendia guardar no banco para alguma emergência). Quanto aos demais, assinalou o desconhecimento e a imprevidência com que tratavam os assuntos financeiros:

Ele não sabe contar dinheiro. Queria comprar uma galinha assada por 15 reais. Disse que não tinha dinheiro bastante, mas estava com três notas de 10 reais. Bastava dar duas notas e a moça do restaurante daria o troco.

Outro pegou uma pepita de quinhentos gramas. Juntou mais um tanto e chegou a um quilo de ouro. Vendeu para Moacir Crocetta (Vilhena), que mandou 10 mil reais pelo banco. Ele gastou aos poucos. Não pegou nada de valor e o dinheiro acabou.

Nas relações de permuta com agentes econômicos externos, "liberar de madeireiro" e "liberar de garimpeiro" constituem as formas verbais pitorescas por meio das quais autorizam a extração de madeira, ouro ou diamante, uma vez fixadas as condições do "acordo" entre as partes (seja a retribuição em dinheiro, mercadorias, equipamentos ou serviços). E, no sentido oposto, "prender" indica a paralisação das atividades de exploração ou a apreensão de bens ou pessoas, com o objetivo de coagir os responsáveis a um pagamento ou uma indenização.

Em novembro de 1999, na aldeia de Mineiro, onde os moradores não negociavam diretamente ou recebiam dinheiro, anotei comentários satíricos acerca das relações com os madeireiros, como esta su- gestão: "No próximo ano vamos fazer diferente. Vamos prender madeireiro!". Estavam agastados com a situação, porque o madeireiro tratava apenas com o "representante" da aldeia, e este não repassara mais que um Toyota velho e um pouco de mercadoria. No mesmo sentido, a expedição que os moradores da aldeia Taquaral organizaram em agosto de 1999, atrás de madeireiros que haviam invadido a região do rio Amarelinho, visava extorquir-lhes $150 \mathrm{mil} \mathrm{re-}$ ais, conforme justificou o zapivaj: "as pessoas querem roupa, coisas, querem mais; e precisa dinheiro". E um informante do posto Rio Preto, que recebera do madeireiro uma espingarda reformada, mas queria uma automática nova, exigia uma troca mais favorável: "Estamos vendendo madeira, quero coisa boa".

Grosso modo, as cobranças crescem à medida que os recursos escasseiam, ou quando estes são amealhados por líderes ambiciosos embora mesquinhos. Em setembro de 1998, após uma pesquisa infrutífera nas imediações da cachoeira Pavorosa, na margem esquerda do rio Branco, um homem censurou duramente o zapivaj da aldeia Bananal, irmão de seu pai: “Comeu tudo madeira. Está na barriga dele." Noutra ocasião, ele confrontou-o diretamente, após destruir as "caixas" de despescagem do garimpo e ameaçar queimar os motores. Pintado de urucum, caminhou do posto Rio Preto até a aldeia Bananal com a intenção de matar seu tio paterno porque este lhe recusou o dinheiro de que precisava - para o tratamento do filho doente e a aquisição de dois butijões de gás. Lá chegando, gritou-lhe palavras ásperas, mas o tio não retrucou. Ainda irritado, criticou-o duramente ao me relatar estes fatos: "Só pega para ele. Eu também tenho família. Preciso de três gramas, quatro gramas para fazer compra. Ele não dá.”

\section{Um regime assimétrico}

Talvez não seja por acaso, afinal de contas, que os recursos naturais (madeira, ouro e diamante) explorados pelos Cinta-Larga, assim como pelos demais Tupi-Mondé, ajustem-se tão bem às demandas da economia regional. Mesmo assim, persiste certo desinteresse no que tange a uma equivalência estrita entre, por exemplo, o valor de mercado da madeira retirada e o montante pago pelos madeireiros - sequer os próprios líderes indígenas se preocupam com procedimentos comerciais ou contábeis mais regulares. Em seu lugar, aplicam aos negócios uma tática pendular, que oscila entre acordos prévios ("liberar") e ações de retaliação ("prender").

É assim, portanto, que as trocas comerciais ali subentendem uma forma de reciprocidade, igualmente "generosa", a mesma que estrutura a socieda- 
de cinta-larga segundo um regime ontologicamente assimétrico. Pois, ainda que as lideranças e as associações indígenas não recebam mais que uma pequena parcela do valor de mercado e que subterfúgios e trapaças sejam frequentes nas negociações, sobretudo a cooptação de lideranças - através da "doação" de carros (por vezes roubados), armas, prostitutas, bebidas, drogas -, a venda de madeira e a exploração garimpeira são as principais e mais seguras fontes de ingresso monetário para as muitas vicissitudes atuais alimentos, moradia (na aldeia e na cidade), transporte e mesmo atendimento médico, remédios e educação escolar para os filhos.

Neste cenário, a coação e a hostilidade, em muitos casos, continuam a lhes servir de instrumento de negociação interna e externa, ao proporcionar um realinhamento entre a quantidade de madeira "liberada", por exemplo, e a retribuição ou a "ajuda" dos madeireiros. É o que se poderia chamar de "tática de extorsão permanente": quando insatisfeitos ou movidos pelo desejo de novas reivindicações (veículos, dinheiro ou outras benesses), os Cinta-Larga ameaçam parar a retirada de madeira, sequestrar o maquinário e agredir os madeireiros e seus prepostos. Se a "lei da oferta e da procura", no mercado capitalista, responde pela formação de preço das mercadorias, por comparação, talvez se possa compreender a ameaça e a violência, na sociedade cinta-larga, como uma espécie de mecanismo regulatório, que ajusta o "valor de troca" em uma "economia simbólica da predação".

As transformações que se observam entre os Cinta-Larga, portanto, revelam um esquema de características dinâmicas, cujo princípio de reciprocidade assimétrica os impulsiona precisamente ao que lhes é exterior, incorporando-o então a si. E os interesses e as necessidades de que esta forma de reciprocidade se reveste - interesses e necessidades culturalmente orientados e, ao mesmo tempo, historicamente constituídos - mobilizam os negócios e as articulações com a população regional, de modo a angariar os bens e os serviços desejados.

\section{Referências}

ALBERT, Bruce \& RAMOS, Alcida (Orgs.). Pacificando o branco: cosmologias do contato no Norte-Amazônico. São Paulo: Ed. Unesp, 2002.

ARISTÓTELES. Ética a Nicômaco. In: Os pensadores, v. 2. São Paulo: Nova Cultural, 1987.

BECKER-DONNER, Etta. Notizen über einige Stamme an den rechten Zuflüssen des Rio Guaporé. Archiv für Volker kunde, v. 10, p. 275-343, 1955.

CARNEIRO DA CUNHA, Manuela \& VIVEIROS DE CASTRO, Eduardo. Vingança e temporalidade: os Tupinambá. Journal de la Société des Americanistes, v. 71, p. 129 208, 1985.

CLASTRES, Pierre. A sociedade contra o Estado. Rio de Janeiro: Francisco Alves, 1978.

CLASTRES, Pierre. Arqueologia da violência: ensaio de antropologia política. São Paulo: Brasiliense, 1982.

DAL POZ, João. Dádivas e dívidas na Amazônia: parentesco, economia e ritual nos Cinta-Larga. 2004. Tese (Doutorado) - Universidade Estadual de Campinas, Campinas, 2004.

DAL POZ, João. Homens, animais e inimigos: simetrias entre mito e rito nos Cinta Larga. Revista de Antropologia, v. 36, p. 177-206, 1993.

DAL POZ, João. No país dos Cinta Larga: uma etnografia do ritual. 1991. Dissertação (Mestrado) - Universidade de São Paulo, São Paulo, 1991.

DILLEY, Roy. Contesting markets: a general introduction to market ideology, imagery and discourse. In: DILLEY, Roy (Ed.). Contesting markets. Edinburgh: Edinburgh University Press, 1992. p. 1-34.

DU BOIS, Cora. The wealth concept as an integrative factor in Tolowa-Tututni culture. In: LOWIE, Robert
H. (Ed.). Essays in Anthropology presented to A. L. Kroeber. Berkeley: University of California Press, 1936. p. 49-66. FAUSTO, Carlos. Inimigos fiéis: história, guerra e xamanismo na Amazônia. São Paulo: Ed. da USP, 2001.

FISHER, William H. Rain forest exchanges: industry and community on an Amazonian frontier. Washington: Smithsonian Institution Press, 2000.

FOUCAULT, Michael. As palavras e as coisas. São Paulo: Martins Fontes, 1985.

GORDON, Cesar. Economia selvagem: ritual e mercadoria entre os índios Xikrin-Mebêngôkre. São Paulo: Ed. da Unesp; ISA; Rio de Janeiro: Nuti, 2006.

GOULDNER, Alvin W. The norm of reciprocity: a preliminary statement. American Sociological Review, v. 25, n. 2, p. 161-178, 1960.

HARGREAVES, Maria Inês S. et al. Levantamento sócio ambiental do Grande Aripuanã. Brasília: Funai. Inédito, 1993. $100 \mathrm{p}$.

JUNQUEIRA, Carmen. Os Cinta Larga. Revista de Antropologia, v. 27/28, p. 213-232, 1984/1985.

KOPYTOFF, Igor. The cultural biography of things: commoditization as process. In: APPADURAI, Arjun (Ed.). The social life of things: commodities in cultural perspective. Cambridge: Cambridge University Press, 1986. p. 64-91.

LATOUR, Bruno. Jamais fomos modernos. São Paulo: Editora 34, 1994.

LEFORT, Claude. A troca e a luta dos homens (1951). In: As formas da história. São Paulo: Brasiliense, 1979. p. 21-35.

LÉVI-STRAUSS, Claude. Guerra e comércio entre os índios da América do Sul (1942). In: SCHADEN, Egon 
(Org.). Leituras de etnologia brasileira. São Paulo: Cia. Editora Nacional, 1976. p. 325-339.

LOWIE, Robert H. Some aspects of political organization among the American aborigines. Journal of the Royal Anthropological Institute, v. 78, n. 1/2, p. 11-24, 1948.

MARX, Karl. O capital: crítica da economia política (1867). v. 1. São Paulo: Abril Cultural. 1983. (Os Economistas).

PARRY, Jonathan \& Bloch, Maurice. Introduction. In: PARRY, Jonathan; BLOCH, Maurice (Eds.). Money and the morality of exchange. Cambridge: Cambridge University Press, 1989. p. 1-32.

POLANYI, Karl. Aristotle discovers the economy (1957a); The economy as instituted process (1957b). In: POLANYI, Karl et al. (Eds.). Trade and market in the early empires: economies in history and theory. Chicago: Free Press, 1957. p. 64-94, 243-270.

SAHLINS, Marshall. Cultura e razão prática (1976). Rio de Janeiro: Zahar, 1979.

SAHLINS, Marshall. Poor man, rich man, big-man, chief: political types in Melanesia and Polinesia. Comparative Studies in Society and History, v. 5, p. 285-303, 1963.
SAHLINS, Marshall. Stone age economics. Chicago/New York: Aldine-Atherton, 1972.

SIMMEL, Georg. Faithfulness and gratitude (1908). In: WOLFF, Kurt H. (Org.). The sociology of Georg Simmel. Glencoe: Free Press, 1950. p. 379-395.

STRATHERN, Marilyn. The gender of the gift. Berkely: University of California Press, 1988.

THURNWALD, Richard. Banaro society: social organization and kinship system of a tribe in the interior of New Guinea. Memoirs of the American Anthropological Association, v. 3, p. 251-391, 1916.

VIVEIROS DE CASTRO, Eduardo. Alguns aspectos da afinidade no dravidianato amazônico. In: VIVEIROS DE CASTRO, Eduardo; CARNEIRO DA CUNHA, Manuela (Orgs.). Amazônia: etnologia e história indígena. São Paulo: NHII-USP/Fapesp, 1993. p. 149-210.

VIVEIROS DE CASTRO, Eduardo. Araweté: os deuses canibais. Rio de Janeiro: Jorge Zahar, 1986.

VIVEIROS DE CASTRO, Eduardo. Os pronomes cosmológicos e o perspectivismo ameríndio. Mana, v. 2, n. 2, p. 115-144, 1996.

\title{
Money and reciprocity in the Cintas-Largas: notes for a political economy in the southern Amazonia
}

\begin{abstract}
Among the Cintas-Largas, through a continuous flow of goods and services, the interests of the political chief are intertwined with those of the residents of his village. And, in the contemporary context of their exterior relations, a kind of qualitative accounting of agreements and debts (about the trade of timber and the exploitation of mines), associates them with a wide range of actors and social. Thus, instances of negotiation and mechanisms of financial control became an extended space of disputes between heads, villages and associations. This article describes the local forms of ownership, circulation and use of money, which evidence the semantics of the "hunt money" that they developed over the last three decades.
\end{abstract}

Key words: Cinta-Larga, Tupi-Mondé, southern Amazonia, political economy, ethnography of money.

\section{Dinero y reciprocidad en los Cintas-Largas: notas hacia una economía política en la Amazonia meridional}

\begin{abstract}
Resumen
Entre los Cintas-Largas, a través de un continuo flujo de bienes y servicios, los intereses del jefe político se entrelazan con los de los residentes de su aldea. En el contexto actual de sus relaciones exteriores, una especie de contabilidad cualitativa de los acuerdos y de las deudas (sobre la venta de la madera y la explotación de minas), los asocia a una amplia gama de actores e instituciones sociales. Así, los foros de negociación y los mecanismos de control financiero se convirtieran en un espacio ampliado de litigios entre jefes, aldeas y asociaciones. Este artículo describe las formas locales de la propiedad, la circulación y el uso del dinero, que muestran la semántica del endineramiento que se ha desarrollado en los últimos tres decenios.
\end{abstract}

Palabras-clave: Cinta Larga, Tupi-Mondé, Amazonia meridional, economía política, etnografía del dinero.

Data de recebimento do artigo: 20/12/2009

Data de aprovação do artigo: 26/4/2010 